\title{
A model for grid cells where spatially correlated place cells compete for the grid map nodes
}

\author{
Luísa Castro ${ }^{1,2}$, Paulo Aguiar ${ }^{1,2^{*}}$ \\ From Twenty Second Annual Computational Neuroscience Meeting: CNS*2013 \\ Paris, France. 13-18 July 2013
}

Grid cells in the medial entorhinal cortex (mEC) encode space in a particular way: their firing rate intensity forms an equilateral triangular lattice as the animal moves in the environment [1]. Models addressing the generation of grid fields fall into two major classes, both with important limitations [2]. Most models based on interference of oscillations are not robust to noise and suffer from the prerequisite of two independent and stable network oscillations with similar frequency. Models based on recurrent networks, where the grid pattern emerges as a stable state of the network, suffer from the topographic assumption and the need for dense recurrent connections between mEC cells, which are both not supported by experimental data.

Here we present a novel firing rate model for the generation of grid fields with two very important features: i) grid fields are built on the spatial information provided by place cells, and ii) plasticity on the synapses between place cells and grid cells depend on the place cell's activity, and therefore depend on space. First, grid cells are driven by the synaptic input provided by the population of place cells. We therefore assume that place cells are the main source of spatial information reaching grid cells, which is in agreement with their development order [3]. Secondly, synapses between place cells and grid cells are subject to a learning process which depends both on pre-synaptic activity, therefore depending on spatial location, and on post-synaptic activity. Plasticity is triggered when the grid cell's activity is above a threshold value. Synaptic efficacies are discrete $\left(w_{-}<w_{0}<w_{+}<w_{++}\right)$and their change depends on presynaptic place cell activity. Four firing rate domains are considered and the synaptic change for each domain,

\footnotetext{
* Correspondence: pauloaguiar@fc.up.pt

'Departamento de Matemática, Faculdade de Ciências da Universidade do Porto, Porto, Portugal

Full list of author information is available at the end of the article
}

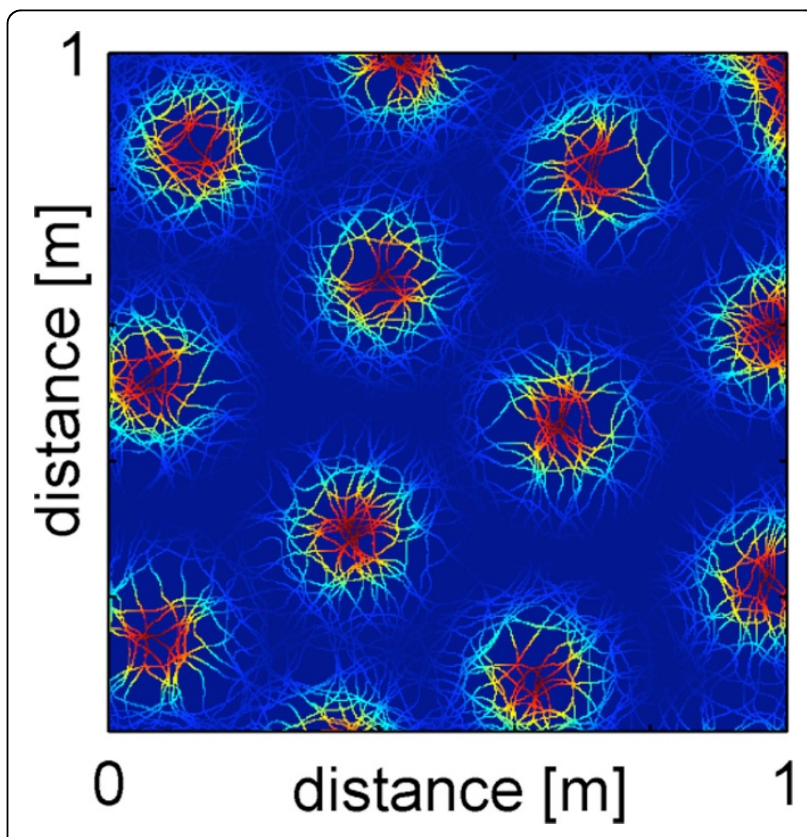

Figure 1 Average firing rate of a single simulated grid cell as a function of the rat's position (blue to red: 0 to $20 \mathrm{~Hz}$ ).

from low to high, is: static, $w_{0}$; potentiated $w_{+}$; depressed, $w_{-}$; potentiated, $w_{++}$. When a synapse $w_{+}$is potentiated again its efficacy is raised to $w_{++}$.

\section{Conclusions}

With the direct input of place cells to grid cells and with the plasticity rule previously described, spatially correlated place cells compete to form the nodes of the grid map. As the animal explores the environment, some place cells are selected over the others to build the grid field. After approximately 30 minutes of exploring randomly an unfamiliar 1 meter square maze, the grid map emerges (see Figure 1). The gridness scores for the resulting grid maps are above 1 . The synapses 
mediating this mechanism can represent the connections between cells in CA1 and the deep layers of $\mathrm{mEC}$. An important feature of this model is that the formation of grid fields is not unique to spatial information: a regular firing rate lattice can be formed from an input population with competing neurons tuned for non-spatial information. Overall, our model is in close agreement with the recently discovered grid cells in primates' visual system [4] and in bat's cortex [5].

\section{Acknowledgements}

Supported by Fundação para a Ciência e a Tecnologia (FCT) through the Centro de Matemática da Universidade do Porto. Luísa Castro was supported by the grant SFRH/BD/46329/2008 from FCT.

\section{Author details}

${ }^{1}$ Departamento de Matemática, Faculdade de Ciências da Universidade do Porto, Porto, Portugal. ${ }^{2}$ Centro de Matemática da Universidade do Porto,

Porto, Portugal.

Published: 8 July 2013

\section{References}

1. Hafting T, Fyhn M, Molden S, Moser MB, Moser El: Microstructure of a spatial map in the entorhinal cortex. Nature 2005, 436(7052):801-806.

2. Giocomo LM, Moser MB, Moser El: Computational models of grid cells. Neuron 2011, 71(4):589-603.

3. Langston RF, Ainge JA, Couey JJ, Canto CB, Bjerknes TL, Witter MP, Moser El, Moser MB: Development of the spatial representation system in the rat. Science 2010, 328(5985):1576-1580.

4. Killian NJ, Jutras MJ, Buffalo EA: A map of visual space in the primate entorhinal cortex. Nature 2012, 491(7426):761-764.

5. Yartsev MM, Witter MP, Ulanovsky N: Grid cells without theta oscillations in the entorhinal cortex of bats. Nature 2011, 479(7371):103-107.

\section{doi:10.1186/1471-2202-14-S1-P2}

Cite this article as: Castro and Aguiar: A model for grid cells where spatially correlated place cells compete for the grid map nodes. $B M C$ Neuroscience 2013 14(Suppl 1):P2.

\section{Submit your next manuscript to BioMed Central and take full advantage of:}

- Convenient online submission

- Thorough peer review

- No space constraints or color figure charges

- Immediate publication on acceptance

- Inclusion in PubMed, CAS, Scopus and Google Scholar

- Research which is freely available for redistribution

Submit your manuscript at www.biomedcentral.com/submit 